\title{
The Emergence of Primary Care in Latin America: Reflections from the Field
}

\author{
William B. Ventres, $M A, M D$
}

A U.S. family physician educator working in El Salvador, recently returned from the WONCA Fourth Regional Congress of the Ibero American Confederation of Family Medicine, reflects on the state of primary care in Latin America. Progress in primary health care and family medicine is occurring in several countries in the region as many countries are coming to accept that primary care is a systematic solution to their structural problems. The author discusses reasons for this progress in the context of political, economic, medical, and cultural dynamics. He notes several key points of comparing this development with the health care system in the United States and suggests that there is much to learn from those systems that are making their way on the path toward primary care. (J Am Board Fam Med 2013; 26:183-186.)

Keywords: Community Medicine, Delivery of Health Care, Family Medicine, Primary Health Care, World Health

I recently returned from 10 days in Cuba to my adopted country of El Salvador. In both countries, I have played the part of visitor. Sometimes I have had the chance to fit into the role of professor or academic scholar-as a Senior Fulbright Scholar funded by the U.S. Department of State, that is what I came south to do. Most often, however, I am in the role of learner. In Havana I was in that role as one of a small contingent of North American attendees at the WONCA Fourth Regional Congress of the Confederación Iberoamericana de la Medicina Familiar (CIMF, or Ibero American Confed-

This article was externally peer reviewed.

Submitted 25 May 2012; revised 14 September 2012; accepted 25 September 2012.

From the Master's Program in Public Health, School of Medicine, and the Institute for Studies in History, Anthropology, and Archeology, University of El Salvador, San Salvador; and the Department of Family Medicine, Oregon Health and Sciences University, Portland.

Funding: Dr. Ventres was a Senior Fulbright Scholar and received funding from the Fulbright Program of the US Department of State. Neither the Fulbright Program nor the US Department of State had any role in the preparation, review, or approval of the manuscript. The views expressed in this article are those of the author and do not reflect those of the U.S. Department of State, the Institute of International Education, or the Fulbright Program.

Conflict of interest: none declared.

Corresponding author: William B. Ventres, Programa de Maestría en Salud Pública, Universidad de El Salvador Facultad de Medicina, Edificio "La Rotonda", $2^{\text {ndo }}$ Piso, Final Calle Arce y 25 Avenida Sur, San Salvador, El Salvador (E-mail: wventres@gmail.com). eration of Family Medicine). In El Salvador I am often in that role as the sole faculty member from the United States at the University of El Salvador, where I have been teaching in their School of Medicine's Master's in Public Health program.

Both countries, one in the Caribbean and the other in Central America, are low- to middle-income countries that are significantly struggling under markedly different economic systems. ${ }^{1,2}$ Cuba is fundamentally a state-run economy; El Salvador is entrenched in the globalized market economy as a member of the Central American Free Trade Agreement. Both face significant external and internal political pressures that frame the daily lives of their citizens. ${ }^{3-7}$ Yet as both a family medicine and public health physician, what has been most striking about my stays in each of these countries is the attention paid to primary health care as a systematic solution to their structural problems.

Cuba has a long history of promoting community-based responses to the health concerns of its people, which started soon after approximately half of its physicians left the country in the years immediately after $1959 .{ }^{8}$ Two notable occurrences strengthened Cuba's focus on primary health care. In 1984 the government decided to make family medicine (médicina general integral, or comprehensive general medicine) the foundation of its medical system, using physicians, nurses, and social workers 
in a model that essentially linked public health and tertiary health care. ${ }^{9}$ Then in 2004 it moved to concentrate undergraduate medical education (in all its medical schools regionally distributed across the country) on training physicians for careers in community-based family medicine. ${ }^{10}$ Although there is some discussion about timing and extent-all things Cuban seem rife for debate given the political tensions that still exist ${ }^{11,12}$-it is generally recognized by the Pan American Health Organization and other observers that the Cuban population has witnessed significant improvements in its health indices because of this primary care orientation. ${ }^{13,14}$

El Salvador is a more recent convert to primary health care within medicine. It has for many years used community health workers as a foundation for health development; the movement first came into existence during the 1980s. ${ }^{15}$ Much more recently, however, as part of an ambitious 8-point plan to reform the public health system (Table 1), the government has made the establishment of decentralized, team-based health clinics the centerpiece of its ambitious health care reform. ${ }^{16}$ In these clinics (Community Oriented Family Health Teams or ECOS-Familiar), generalist physicians, nurses, community health workers, and a multipurpose staff member work collaboratively in economically marginalized parts of the country. Despite significant financial and political issues that have limited the implementation of the overall health reform-the country spends only $3.9 \%$ of its gross domestic product on health expenditures ${ }^{2}$ - human and capital resources in primary care have expanded by approximately $25 \%$ since $2009 .^{17}$

\section{Table 1. Eight Key Points in El Salvador's Health Care Reform $^{16}$}

1. Establish a comprehensive integrated network of health services, focusing on community based health teams.

2. Develop a national system for handling medical emergencies.

3. Improve availability and quality of medicines and immunizations.

4. Coordinate health services through an cross-disciplinary health commission.

5. Establish a national health forum.

6. Create a national public health institute.

7. Design and implement one national epidemiological tracking system.

8. Reorient human resources toward accomplishing these reforms.
What was most striking about the CIMF meeting was that such moves toward implementing primary health care models have not been limited to Cuba and El Salvador. Brazil, Peru, Paraguay, and Venezuela have developed or are developing models that rely on general and family physicians for the future, and other countries are following their lead. ${ }^{18-21}$ Although some countries involved have looked at the Cuban system for philosophical guidance as well as functional leadership-the Venezuelan plan still relies heavily on Cuban physicians to staff both its Barrio Adentro (service) and General Community Medicine (educational) programsothers, notably Brazil's Family Health Program, got their start under vastly different circumstances. ${ }^{21,22}$

Why do medical care systems based on primary health hold such promise in Cuba, El Salvador, and the rest of Latin America? First, the cultures in these countries (as in almost all other countries around the world) are traditionally more collectively oriented than that of the United States. ${ }^{23}$ High value traditionally has been placed on family and community, a characteristic that can help support local primary care practices. Second, significant political power will go to those who can implement reasonably functioning health care systems, given that many of these countries are newly democratic. Several have had universal health care plans, albeit marginally functional ones, on the books for decades, and transitioning to models based on primary care makes rational sense to the public health leaders that set policy in these countries. ${ }^{24}$ Third, many countries in Latin America are coming to recognize the impossibility of continuing down the subspecialist road if they want to extend access to care, especially considering that large proportions of people in most of these countries live in poverty; in El Salvador, for example, the poverty rate nears $40 \% .^{2}$ It is increasingly understood that primary health care services are an economically efficient means of providing highquality services, even when there are strong local and global stakeholders (including subspecialty societies, the pharmaceutical industry, and tertiary medical centers) that still impede the development of more rational health care systems. ${ }^{24-27}$ Fourth, these countries have traditionally seen the United States as a power that has intervened in their internal affairs for well more than 100 years. ${ }^{28}$ The psychological and economic advantages of creating uniquely national systems of primary health care cannot be underestimated. ${ }^{29}$ 
In Latin America one frequently hears echoed critical perspectives about the condition of U.S. health care system. Professional colleagues here in El Salvador commonly note that the United States has done a very poor job of creating a functioning primary health care system within its own borders. ${ }^{30}$ As a singular entity it is poorly positioned to offer substantive advice on the implementation of primary health care systems based on its own record of not providing the same to its own people. ${ }^{31}$ It is complicit in the migration of valuable human resources to feed its growing need for health care personnel. ${ }^{32}$ As well, its focus on technocentric, individualistic, biomedically focused solutions to global health problems has severe limitations in places that share neither the resources, cultures, or political realities that are dominant in the United States. ${ }^{33}$

South-south collaboration in medicine and public health has been talked about for some time, and in Latin America it seems that such international cooperation is gaining strength with the emergence of primary care. The CIMF meeting brought this cooperative spirit clearly into view: it was a meeting full of thoughtful exchanges and collaborative conversations about this development. Time will tell whether Latin American countries are able to pull themselves out from under the dominance of a subspecialty medical model borrowed, if not overtly copied, from their large neighbor to the north. Time will tell whether they can create systems founded on family medicine principles that are successful despite other medical, political, and economic influences that stand in the way of a sensible systematic change toward primary care. But if they are successful, maybe then it will be time for those in the United States to look south for guidance, so that it too can develop a primary health care system based on patient-, family-, and community-centered values. Then, perhaps, it will be time for us all to assume the role of learner and seek guidance from others as we make our way on the path toward primary health care.

\section{References}

1. Central Intelligence Agency. The World Factbook: Cuba [Internet]. Available from: https://www.cia. gov/library/publications/the-world-factbook/geos/ cu.html. Accessed September 13, 2012.

2. Central Intelligence Agency. The World Factbook: El Salvador [Internet]. Available from https://www. cia.gov/library/publications/the-world-factbook/geos/ es.html. Accessed September 13, 2012.

3. UNHCR. Cuba: routine repression: political shortterm detentions and harassment in Cuba [report on the Internet]. March 22, 2012. Geneva: UNHCR. Available from: http://www.unhcr.org/refworld/docid/ 4f6c5da22.html. Accessed September 13, 2012.

4. Fariña LP, Miller S, Cavallaro, JL. No place to hide: gang, state, and clandestine violence in El Salvador. Cambridge, MA: International Human Rights Clinic, Human Right Program, Harvard Law School; 2010.

5. Suddath C. A brief history of U.S.-Cuba Relations [article on the Internet]. Time, April 15, 2009. Available from: http://www.time.com/time/nation/article/ 0,8599,1891359,00.html. Accessed September 13, 2012.

6. Equipo Maiz, Historia de El Salvador: De cómo la Gente Guanaca no Sucumbió ante los Infames Ultrajes de Españoles, Criollos, Gringos, y Otras Plagas. San Salvador, El Salvador: Asociación Equipo Maiz; 2008.

7. Moodie E. El Salvador in the Aftermath of Peace: Crime, Uncertainty, and the Transition to Democracy. Philadelphia: University of Pennsylvania Press; 2010.

8. Whiteford LM, Branch LG. Primary Health Care in Cuba: The Other Revolution. Lanham, MD: Rowman and Littlefield Publishers, Inc.; 2007.

9. Mason SE, Strug DL, Beder J, eds. Community Health Care in Cuba: An Enduring Model. Chicago: Lyceum Press. 2009.

10. Pernas M, Arencibia LG. Changes needed in basic biomedical sciences in Cuban medical schools. MEDICC Rev 2012;14:41-4.

11. Hirschfeld K. Health, Politics, and Revolution in Cuba Since 1898. New Brunswick, NJ: Transaction Publishers; 2008.

12. Kath E. Social Relations and the Cuban Health Miracle. New Brunswick, NJ: Transaction Publishers; 2010.

13. Pan American Health Organization/World Health Organization. Health in the Americas. Volume IICountries: Cuba [report on the Internet]. Washington, DC: Pan American Health Organization; 2007. Available from: www.paho.org/hia/archivosvol2/ paisesing/Cuba\%20English.pdf. Accessed September 13, 2012.

14. Keck CW, Reed GA. The curious case of Cuba. Am J Public Health 2012;102:e13-22.

15. Nonini-Smith S. Healing the Body Politic: El Salvador's Struggle for Health Reform From Civil War to Neoliberal Peace. New Brunswick, NJ: Rutgers University Press; 2010.

16. Rodriguez MI, Espinosa E, Menjívar V. Building hope: strategies and recommendations for health [report on the Internet]. San Salvador, El Salvador: MINSAL; 2009. Available from: http://www.salud. 
gob.sv/index.php/servicios/descargas/documentos/ Documentaci\% C3\% B3n-Institucional/Pol\% C3\% ADtica-Nacional-de-Salud/Health-Policy-El-SalvadorBuilding-Hope/. Accessed September 13, 2012.

17. Ministerio de Salud de El Salvador. Informe de labores 2011-2012 [report on the Internet]. San Salvador, El Salvador: MINSAL; 2012. Available from: http://www.salud.gob.sv/index.php/servicios/ descargas/documentos/Documentaci\%C3\%B3nInstitucional/Memorias-de-Labores/Memoria-deLabores-2011-2012/Informe-de-Labores-2011-2012/. Accessed September 13, 2012.

18. Blasco PG, Levites MR, Janaudis MA, et al. Family medicine education in Brazil: challenges, opportunities, and innovations. Acad Med 2008;83:684-90.

19. Harris M, Haines A. Brazil's family health programme. BMJ 2010;341:c4945.

20. Suárez-Bustamante MA. La medicina familiar en el Perú: evolución y desafíos. Rev Peru Med Exp Salud Pública 2008;25:309-15. Available from: www.scielo. org.pe/pdf/rins/v25n3/a10v25n3.pdf. Accessed September 13, 2012.

21. Muntaner C, Armada F, Chung Haejoo, et al. Venezuela's Barrio Adentro: participatory democracy, south-south cooperation and health care for all. Soc Med 2008;3:232-46. Available from: http://www. socialmedicine.info/index.php/socialmedicine/article/ view/250/531. Accessed September 13, 2012.

22. Barreto ML, Aquino R. Recent positive developments in the Brazilian health system. Am J Public Health 2009;99:8.

23. Hofstede G, Hofstede GJ. Cultures and Organizations: Software of the Mind. New York: McGrawHill; 2005.
24. Pan American Health Organization. Renewing primary health care in the Americas: a position paper of the Pan American Health Organization/World Health Organization (PAHO/WHO) [report on the Internet]. Washington, DC: Pan American Health Organization; 2007. Available from: www.paho.org/ english/AD/THS/PrimaryHealthCare.pdf. Accessed September 13, 2012.

25. Starfield B, Shi L, Macinko J. Contribution of primary care to health systems and health. Milbank Q 2005;83:457-502.

26. Boelen C, Haq C, Hunt H, Rivo M, Shahady E. Improving Health Systems: The Contribution of Family Medicine. A Guidebook. Singapore: WONCA; 2002.

27. World Health Organization. The world health report 2008: Primary health care now more than ever [report on the Internet]. Geneva: World Health Organization; 2008. Available from: www.who.int/whr/ 2008/whr08_en.pdf. Accessed September 13, 2012.

28. LaFeber $W$. Inevitable Revolutions: The United States in Central America. 2nd ed. New York: W. W. Norton \& Company, Inc.; 1993.

29. Waitzkin H. Medicine and Public Health at the End of Empire. Boulder: Paradigm Publishers; 2011.

30. Ferrer RL. Within the system of no-system. JAMA 2001;286:2513-4.

31. Detsky AS, Guathier SR, Fuchs VR. Specialization in medicine: how much is appropriate? JAMA 2012; 307:463-4.

32. Mullan F. The metrics of the physician brain drain. N Engl J Med 2005;353:1810-8.

33. Rawaf S, DeMaeseneer J, Starfield B. From AlmaAta to Almaty: a new start for primary health care. Lancet 2008;372:1365-6. 